\title{
FROM EUROPE TO LOMBOK: THE DISCOURSE OF LOMBOK TOURISM IN THE NOVEL MEDULLA SINCULASIS
}

\author{
Dharma Satrya HD
}

\author{
dharmasatryahd@gmail.com \\ Universitas Hamzanwadi, \\ Nusa Tenggara Barat, Indonesia
}

\begin{abstract}
This article discusses the discourse of Lombok tourism in Paox Iben's novel Medulla Sinculasis. This article implements Stuart Hall's representation theory, which combines semiotic theory with discourse theory. Therefore, for the methodological implication, this article employs semiotic and discursive methods. The novel "Medulla Sinculasis" was used as semiotic data; meanwhile, Lombok's discourse was considered the discursive data. The semiotic data were used to elucidate Lombok's meaning; meanwhile, the discursive method was used to discover the source of meaning. The findings showed that Lombok in the novel "Medulla Sinculasis" was interpreted as a tourist object. Lombok is constructed as a tourist object. In Lombok, discourse on tourism was initiated by Tuan Guru Bajang, a religious scholar, after he was elected the governor of West Nusa Tenggara, Indonesia, in 2008. Within this context, the novel Medulla Sinculasis is discussed. Lombok as the tourist object is described by Netherlanders, Europe. In this story, Nuruda is driven to visit Lombok after seeing a painting titled Medulla Sinculasis being auctioned at the Van Gogh Museum in the Netherlands. After returning to Indonesia from Europe, Nuruda decides to travel directly to Lombok and meet Husin Nanang, the painter. His meeting with Husin Nanang and the situation in Ampenan City leads Nuruda on a transformation from tourist to social activist, fighting to protect the rights and promote the interests of marginal groups. Nuruda's struggle is ultimately unsuccessful, and he is killed in a hit-and-run. The Lombok in this novel is part of the discourse from the 2000s and 2010s, a period that was dominated by the economization of Lombok. The novel Medulla Sinculasis may be seen as part of this dominant discourse, thus having the economization of Lombok as part of its agenda.
\end{abstract}

Keywords: novel, Lombok, discourse, tourism, economization

\section{INTRODUCTION}

Lombok, Indonesia, has been constructed through three discourses: tradition, Islam, and modernity (Satrya HD, 2018a). These three discourses are present in the humanities, particularly in anthropological, Islamic, and literary studies in Lombok. These three discourses have been contested in the signification of Lombok. In the 1990s and 2000 s, the discourse of tradition was dominant in Lombok's understanding; Islamic and modern discourses, thus, remained marginal. In the 2010s, discourses of Islam and modernity have influenced the signification of Lombok. The local government initiated several book publication projects through its language development and guidance agency, emphasizing tradition by referring to ancient manuscripts as the sources of Lombok cultural values (Mintosih, Lestariningsih, \& Herliswani, 1999).

Meanwhile, the department of education and culture published a book on Sasak etiquette, seeking to preserve ancestral values, traditions, and customs (May et al., 1989). The department of Education and 
Culture (1988) also published a history book in 1988, titled Sejarah Nusa Tenggara Barat (History of West Nusa Tenggara), which understood Lombok within the context of Javanese constructs (Depdikbud, 1988). The name "Lombok" is mentioned within the Negarakertagama, and-according to Dr. R Goris-the term Sasak itself is derived from a Sanskrit word that means "one who leaves one's origin," i.e., referring to Javanese people who traveled to Lombok (Depdikbud, 1988).

Into the $2000 \mathrm{~s}$, the traditional discourse remained strong. It continued until Lukman published his book Tata Budaya Adat Sasak (The Culture and Tradition of the Sasak). In this book, Lukman (2006) presented a further discourse on the Sasak people's traditions and customs, including wedding ceremonies. Lukman (2008) understood Lombok within the context of European discourse. He writes that Lombok means rechts, straight, and links this to discipline in paying taxes (Fauzan, 2013).

In the 2000s, the discourses of Islam and modernity became increasingly influential. As discourse regarding (orthodox) Islam gained power, the tradition discourse and practitioners of traditional Islam, also known as the wetu telu, were increasingly marginalized (Budiwanti, 2000). Asnawi (2005) discussed syncretism within Islamization, while Zaelani (2007) identified pantheism as the theology of the wetu telu. Syakur (2006), meanwhile, argued that the Sasak people had been influenced by Islamic teachings, including aqidah (creed), Syariah (law), muamalah (social interactions), and akhlak (character). Islamic discourses, which had been previously limited to education (such as in Islamic boarding schools), were spread through an ethical policy. Hunter (2004), meanwhile, identified Islam as part of the modern Sasakidentity.

Zulkarnain (2009) writes that the election of Tuan Guru Bajang, an Islamic scholar, as the Governor of West Nusa Tenggara for two periods (2008-2018) gave significant space for orthodox Muslims (wetu lima) to shape the Sasak Islamic identity. At the same time, he was designing the Visit Lombok Sumbawa (VLS) program to promote tourism in West Nusa Tenggara (Mubarok, 2009), Tuan Guru Bajang initiated the construction of an Islamic Centre as an icon of the province
(Mubarok, 2009). In this context, the novel Medulla Sinculasis contributed to the VLS discourse through its presentation of Lombok as a tourism destination.

This article sees the position of the novel in the contestation of discourse. The novel becomes part of that discourse. This article further explores the relationship between ethnic Indonesian literature and tourism. To find the relationship between both, this article used the representation theory of Stuart Hall (1997). This theory assumes that the novel is a production of meaning through language (Hall, 1997). The concept of language in Hall does not refer to Saussure's concept of language, but Barthes' concept regarding the myth, which is at a certain level, can be an ideology. The concept of language is related to the broader concept of language, namely discourse. Hall combines the semiotic approach and discursive approach to find the meaning and the source of meaning. Lombok's meaning in Medulla Sinculasis can only be found using the analysis of semiotic and the source of meaning combined with discursive analysis. The theory of Stuart Hall is used to find the relationship of Indonesian ethnical literature with tourism. Using Hall's theory, this article combines two fields of study that are rarely explored by the researchers of Indonesian literature (ethnic). In that context, this article is essential to be observed, especially its contribution.

The theory of Stuart Hall implies the combination of the semiotic and discursive method. The semiotic analysis is conducted to find Lombok's meaning in the novel Medull Sinculasis; meanwhile, the discursive analysis is conducted to find the source of meaning. Meaning is the sign itself. It is the politeness between the marker and another marker, whether in the level of connotation. The sign in the level of denotation serves as the data. The statement regarding Lombok produced by the book or other scientific works is deemed as the discursive data. The signs in the novel Medulla Sinculasis, including the events, are connected to the discourse novel. The sign in the novel refers to the meaning of Lombok as a tourism object. The meaning is produced by the discourse of tourism in Lombok. The discourse is the dominant discourse in the reformation era. The discourse forms the subject of the governor of West Nusa Tenggara, Indonesia. 
The discourse of Lombok as a tourism object is the discourse appearing in the colonization era.

\section{ETHNICITY DISCOURSE IN LITERATURE}

Ethnicity discourse in literature is rooted in ethnic minority groups' desire to express their own identities within the national literature (Sesnic, 2007). Traditional themes, for example, have coloured the works of Japanese-American, Chinese-American, and Indian-American authors (Bear et al., 1987). Oliver (1991) has argued that such writings are part of an effort to resist Anglo-Americans' attempts to homogenize American literature. Writers from ethnic minorities are only rarely represented in the literary canon (Gilman, 1998).

Sesnic (2007) has examined the rise of minority authors and their explorations of their ethnicidentities in the United States. This process has been marked by twin discourses of mourning and melancholy in American literature (Sesnic, 2007), used to construct ethnic identity. Ramachandran and Hashim (2014) have shown how literary writing can reflect ethnic ideologies and ethnicities.

Ethnicity can only be represented through literature. If literature is assumed to be a discourse, then-in the context of ethnicity-literature constructs a specific ethnic identity. This construction of ethnicity, of course, is the construction of the self by the independent subject. Efforts to assert oneself as a subject are undertaken to reject the selfs monolithic constructions within specific places and times. In the United States, it is the AngloAmerican identity challenged by ethnic minorities such as Chinese Americans, Japanese Americans, and Indian Americans. In Britain, meanwhile, British Blacks have attempted to find their voice (Fernandez, 2009). It is in this context that Satrya (2018a) has examined ethnicity within contemporary Indonesian literature.

\section{ETHNICITY WITHIN INDONESIAN LITERATURE}

An awareness of ethnicity has emerged within Indonesian literature. Soedjijiono (2009), for example, examined Pengakuan Pariyem (Pariyem's Confession), Pasar (Market), Para Priyayi (The Noblemen), and Ibu Sinder (Mrs. Sinder) as novels that are characterized by local wisdom. Subardini
(2011) examined the presentation of Balinese culture in Indonesian literature through Oka Rusmini's oeuvre. Suroso (2011), meanwhile, studied Burung-Burung Manyar (The Vultures), Canting (Wax Pipe), Para Priyayi (The Noblemen), Pasar (Market), Bekisar Merah (Red Rooster), Tirai Menurun (The Curtain Falls), and Perempuan Yogya (Women of Yogya) as novels colored by Javanese cultural influences, while Wildan (2013) revealed the Acehnese local wisdom in the novel Seulosoh. Suwignyo (2013) studied Javanese cultural elements present in modern Indonesian poetry, identifying elements such as aja dumeh (be humble), manunggaling kawula gusti (unity of humanity and god), keeping promises, and self-sacrifice (Suwignyo, 2013). Hardiningtyas (2015) examined Bumi Manusia (This Earth of Mankind) as a representation of feudal Javanese culture, which is opposed within the novel by the humanist character Minke (Hardiningtyas, 2015). Wijanarti (2015) described how women with the title nyai are represented in the folktales of Central Kalimantan, arguing that this title is granted to women of great intelligence. Kurnia (2015) revealed the Malay discourses evident in the novels of Andrea Hirata, while Putri (2016) sought an understanding of the Dayak people as presented within the novel Api Awan Asap (Fire Cloud Smoke). Ethnicity, thus, may be seen as typical in Indonesian literature.

The use of ethnicity to underscore regional contributions to Indonesian literature and enrich its oeuvre has been studied by Putra (2017; 2011) in Bali and Satrya (2018a) in Lombok. Putra (2017; 2011) focused on Balinese writers' contributions to the constellation of Indonesian literature through such mass media as Bali Adnjana, Surya Kanta, Bhawanegara, and Djatajoe. Similarly, Satrya (2018a) looked at ethnicity as an issue of representation, examining how ethnicity is understood and what leads to its expression. Within Lombok's context, Satrya (2018a) showed a shift in the representation of Lombok, from feudalism and capitalism to romanticism. Satrya (2018b) also examined the emergence of ethnic poetry in Lombok, taking as his case Kiki Sulityo's expression of Sasak identity within Indonesian literature.

The studies of ethnicity within Indonesian literature mentioned above have 
different points of emphasis-first, ethnicityat the textual level, and second, ethnicity at the social level. The first is linked to literature itself, while the second invokes elements outside the literary work. Within the novel Medulla Sinculasis, ethnicity may be seen from the second perspective, within the regime of representation that dominated Lombok in the 2000s. In Medulla Sinculasis, ethnicity is related to Lombok's position as a tourism destination; it is part of economizing Lombok (Satrya HD, 2018a).

\section{LOMBOK AS A TOURISM DESTINATION From Europe to Lombok}

The novel Medulla Sinculasis presents Lombok's construction as a tourism destination, one that was constructed by Europeans. In this novel, Lombok is promoted as a tourism destination by Europeans in Lombok. For example, Johanna traveled to Lombok on her honeymoon and brought home the painting Medulla Sinculasis as a souvenir. This painting was sold for 300 Euros at a charity event, which was attended by Nuruda. Seeing the painting drew Nuruda's interest in travelling to Lombok.

Nuruda witnessed the auction of the painting while on a trip to the Netherlands, more specifically while visiting the Van Gogh Museum. His visit to the museum and his interest in the painting reminded him of Lombok, where his father was born (Iben, 2011, p. 34).

The novel puts Netherland as the opposition of Lombok. Netherland sees Lombok as a beautiful and natural place, so it is suitable to be a tourism object, a place of joy and happiness. The beauty of Lombok is represented in the medulla sinculasi painting. It brings beauty to the Netherland and puts Netherland as self and Lombok as other. The relationship is represented in the relationship between Jakarta and Lombok. Jakarta as self, meanwhile Lombok as other. Nuruda lives in the culture of Jakarta. That past presents inside him after he goes to Netherland. Johanna, Netherland, so they are in the same polar as Nuruda, Jakarta. Johanna and Nuruda see Lombok as a beautiful place, a tourist object. All of the areas he visited were those on the maps made for tourists.

\section{From Tourist to Social Activist}

The first place Nuruda visited was Senggigi, a common destination for tourists (Kanom, 2015). By carrying a tourism map, Nuruda became a tourist in Lombok (Iben, 2011, p. 50). Nuruda had to travel to Lombok quickly. His life in Jakarta, as well as his girlfriend's decision to abort their unborn child withouthis knowledge, led him to sever all ties with Jakarta.

The novel puts Jakarta as a boring metropolis city; meanwhile, Lombok is described as a beautiful and escaping place. Senggigi beaches are the first destination after arriving in Lombok. However, Senggigi is not the leading destination; instead, Ampenan, the home of a painter, Husin Nanang. His success in meeting Husin Nanang is the success of knowing the background of medulla sinculasis painting. His childhood friend inspires that painting with a bent body (Iben, 2011, p. 51). The next destination is Ampenan, the city where Husin Nanang is from.

Nuruda's meetings with Husin led him to transform himself from a simple tourist and seeker of knowledge into an activist, the instigator of a social movement. Nuruda initiates a social movement with a group of artists and local residents (Iben, 2011, p.78). Their first step is to open an art gallery (Iben, 2011 , p.85); thus, art is used as a social mobilization tool.

This movement, however, was not long-lived. Nuruda was accused of embezzling the financial support they received from some NGOs. He failed to sustain the movement, instead of fleeing to Sembalun, a very traditional region in the shadow of a mountain. There, Nuruda learned about environmental management and conservation. After returning from Sembalun, he attempted to revive his movement. However, many of his opponentsparticularly at a place where he had once worked-decided to remove Nuruda. As a result of this conspiracy, Nuruda was killed in a hit-and-run accident, dying nameless in the street (Iben, 2011, pp. 306-307).

\section{Art Discourses in Medulla Sinculasis}

In the novel, the painting Medulla Sinculasis was not named by Husin Nanang, but rather Johanna. Husin Nanang painted the work before selling it to Johanna when she traveled to Lombok with her husband. When Johanna acquired the painting, Husin had yetto 
give it a title; as such, Johanna referred to medical science and named the painting Medulla Sinculasis. As such, Lombok became understood through medical discourse and health discourse. The Latin term medulla sinculasis refers to a tumor that grows along the spinal cord (medulla spinalis), implying that the hunchbacked boy was suffering from such a tumor. Nuruda considered this painting beautiful, and as such, its aesthetic qualities were dictated by Nuruda's perceptions. Looking at the painting, Nuruda was reminded of the work of Edvard Munch. Did the beauty of Medulla Sinculasis lie in the subject's deformity?

Ruth berhenti di depan lukisan yang belum jadi itu. Ia begitu terpana dengan lukisan seorang laki-laki bongkok yang sedang tersenyum dengan kemaluan menjuntai. Ia tersenyum sendiri dan memanggil suaminya, sementara yang dipanggil diam tak menyahut. Entah tidak dengar atau hanya pura-pura saja. "Tumor pada medulla spinalis," katanya lirih, seperti berkata pada dirinya sendiri. Sebab tak ada seorangpun didekatnya. Di negerinya ia berprofesi sebagai seorang perawat. Sebelumnya ia bergabung dengan unit medical centre di Rotterdam, ia seorang perawat pribadi seorang penderita tumor medulla spinalis di kota asalnya, Amsterdam (Ruth stopped in front of the unfinished painting. She was stricken by the young boy, a smiling hunchbacked figure whose genitals were dangling. She smiled to herself and called her husband... the one she was calling remained silent, either not having heard or pretending not to have heard. "A tumour on the medulla spinalis," she said softly, as if to herself. For therewas nobody near her. In her country, she worked as a nurse. Before joining the medical centre in Rotterdam, she had been the personal nurse to someone suffering from such a tumour in her hometown, Amsterdam) (Iben, 2011, p. 256).

Johanna called this painting Medulla Sinculasis because it reminded her of a patient in her homeland. Johanna had been the personal nurse to that person. Johanna and Nuruda both recognized the painting as aesthetic. However, Johanna's view was rooted in her own experiences as a nurse, while Nuruda examined its aesthetic value based on his love of art.

In this case, the experiences of a nurse influenced the discourse around the painting. As such, Lombok's discourse was one of medicine, of health, and as such one that perceived abnormality as a disease. The boy depicted in the painting was abnormal. However, for Nuruda, the boy in the painting symbolized a people who judged everything through their physical and material characteristics (Iben, 2011, p. 32).

\section{THE NOVEL AS PART OF TOURISM DISCOURSE}

This novel begins with Nuruda undertaking a business trip to Europe, attending a meeting to discuss current sociopolitical conditions. However, its narrative does not focus on this meeting, but rather on Nuruda's visit to a family member in the Netherlands and subsequent trip to the Van Gogh Museum, where he finds an auction intended to raise funds for assisting disaster recovery efforts in Indonesia. The painting Medulla Sinculasis is auctioned for 300 euros. Thus, this part of the novel invites readers to consider Europe's involvement in world affairs, including in disaster assistance. It shows that Europe has contributed significant aid to disaster victims in Indonesia, including through the sale of paintings.

The painting Medulla Sinculasis is sold while Nuruda is visiting the museum. This painting reminds Nuruda of the city where his grandfather was born-Ampenan, Lombokand pushes him to travel to the island. His first destinations in Lombok are those locations marked on his tourist map, including Senggigi, Ampenan, Sembalun, and Mataram City parks. Nuruda obtained his knowledgeabout Lombok from the tourist map and brochures. The narrator, meanwhile, approaches Lombok from a scientific perspective, relying on statistical data.

Lombok merupakan sebuah pulau di wilayah provinsi Nusa Tenggara Barat yang padat penduduknya. Dimana 
terdapat angka kepadatan, di situ muncul persoalan. Angka buruh migrannya cukup fantastis, angka harapan hidup yang sangat rendah, angka kematian ibu melahirkan sangat tinggi, gizi buruk, indeks prestasi manusia yang anjlok dan seterusnya. Nuruda cukup hafal kalimat-kalimat seperti karena selalu menghiasi semua proposal pengajuan dana, baik yang dilakukan oleh pemerintah maupun LSM (Lombok is a densely populated island in West Nusa Tenggara. Where there is population density, there are problems. Migration levels were high, life expectancies were low, maternal deaths were high... malnutrition, poor human resource quality, everything. Nuruda remembered many such statements, as they decorated the pages of all proposals, be they filed by the government or by NGOs) (Iben, 2011, p. 38).

It presents a specific and scientific understanding of Lombok. It presents Lombok in numbers, i.e., the number of migrant workers. Tourism in Lombok is framed similarly.

"Sori, sori...nerocos. Eh, kayaknya pariwisata Lombok sedang bergairah akhir-akhir ini?" Vandesa tahu diri dan mencoba mengalihkan pembicaraan. "Itulah ironi pariwisata," kata Nuruda. Eskalasi konflik terutama konflik agraria sangat meningkat akhir-akhir ini. Tinggal menunguu waktu saja." Nuruda memandang sekitar, membetulkan letak kacamata murahannyaitu.

"Seperti pulau ini, sebagian besar tanah dan cottage-cottage ini milik orang asing. Penduduk lokal hanya jadi pekerja sebagai tukang sampah atau penjaga villa. Padahal dahulu merekalah pemiliknya. Fenomena itu hampir merata di seluruh pulau Lombok. Bahkan banyak tanah-tanah yang dibiarkan kosong. Pemiliknya entah siapa atau di mana. Sebagian memang dimanfaatkan penduduk untuk bercocok tanam. Tapi sebagian besar lainnya dibiarkan melompong." Lanjutnya ("Like this island... most of the land and cottages belong to foreigners. The locals are only workers, maybe garbagemen or watchmen. Even though they were the owners before. This is a phenomenon that can be found throughout much of Lombok. A lot of land is just left empty, its owner unclear. Some of it is used for crops, but much of it is left fallow," he continued.) (Iben, 2011, pp. 125-126).

"Saya juga tidak pernah tahu, siapa yang diuntungkan dari bisnis pariwisata ini. Pemerintah daerah? Nyatanya PAD mereka masih terendah di Indonesia. Tidak signifikan. Kalau dikatakan pariwisata sepi, memang begini tipikal pariwisata Lombok Hanya turis kaya yang mampu menyeberang ke Lombok. Mereka umumnya sudah jenuh dengan Bali karena terlalu padat dan ramai. Mereka pun menyingkir ke Lombok. Makanya banyak hotel dan villa yang justru berada di tempat tersembunyi. Menurut cerita temanku yang manajer sebuah hotel di pantai Sire, bulan lalu Deputi Menteri Keuangan Inggris sempat datang kemari. Nginap di villanya. Ia dan manajer lainnya bahkan tidak pernah tahu siapa tamunya, sampai paparazzi yang menyewa helikopter itu terbang riuh mengambil gambar. Media internasonal heboh, karena sang Deputi itu sedang telanjang ria sama teman gaynya," kata Nuruda ("I've never really known who really benefits from tourism. The regional government? Regional revenues were the lowest in Indonesia. Insignificant. Tourism is limited... that's how things are in Lombok. Only the wealthy tourists can afford to cross over to Lombok. They are generally tired of Bali, with its crowds and its hustle and bustle. They instead choose Lombok. And that's why many of the hotels and villas are in hidden areas. According to one of my friends, the manager of a hotel on Sire Beach, last month the English Deputy Minister of Finance came, stayed at the villa. He and the other managers didn't know who their 
guest was, at least until the paparazzi rented a helicopter and made a commotion. Soon the international media was abuzz with news that the Deputy Minister had been spotted naked with his gay friend," said Nuruda) (Iben, 2011, p. 127).

The novel's tourism narrative centers on the dialog between Nuruda and his girlfriend in Jakarta, Vandesa. Through Nuruda, the narrator discusses the issues related to tourism in Lombok, including land disputes and the people who benefit from tourism. Nuruda does not know the entire story of tourism in Lombok. His knowledge of tourism on the island is obtained not through interactions with Lombok people but rather with outsiders. He deals with hotel managers, not the everyday people who are the victims of tourism development. Nuruda's limited knowledge indicates that his narrative is presented through an outsider's perspective, not one from Lombok itself. The narrator attempts to present the common destinations and locations in Mataram through the character of Tegar, the boy who inspired Husin Nanang to paint Medulla Sinculasis.

Sampai di depan lapangan Sangkareang, ia duduk sebentar di trotoar (When he arrived in front of the Sangkareang field, he sat for a bit on the sidewalk) (Iben, 2011, p. 145).

Ia kemudian menyebrangi perempatan gubernuran dan berhenti untuk rebahan di atas patung buaya yang kepalanya tertanam di lubang saluran air yang terletak di samping pos polisi itu (He then crossed at the governor's office and stopped to rest on the statue of the crocodile, which had its head stuck in the waterway near the police post) (Iben, 2011, p. 145).

Jarak kurang lebih $2 \mathrm{~km}$, Tegar sampai di perempatan Sweta. Di perempatan itu ia memandang sebuah monumen replika Upakarti, penghargaan tertinggi yang diberikan presiden untuk gubernur atau walikota atau bupati untuk keberhasilannya membina ekonomi rakyat (The distance was about 2 kilometres, from Tegar to the Sweta intersection. There he saw a replica of the Upkarti monument, the greatest recognition the president could give a governor, mayor, or regent for their contributions to economic development) (Iben, 2011, p.156).

Arah Timur perempatan itu menunju seluruh pulau Lombok, menyebrang ke pulau Sumbawa sampai Timor Leste. Ke arah Utara menunju Selagalas, lalu orang bisa ke LombokUtara, berendam dan berenang sepuasnya di Gili Tramen (East from that intersection, one could go through all of Lombok, or cross over to Sumbawa and even East Timor. To the north to Selagalas, and then North Lombok, where one could soak and swim at Gili Tramen) (Iben, 2011, p. 157).

This narrative of tourist attractions in Lombok is narrated through Tegar. This narrative introduces readers to the different locations in Mataram City, including Ampenan, where Tegar was born and raised, and where Nuruda lived and mobilized his social movement through art.

\section{THE TOURISM DISCOURSE IN LOMBOK}

The Dutch government constructed Lombok as a tourism area in the 1900s (Illustrated Tourist Guide to East Java, Bali, and Lombok, 1914). However, the Lombok Government started it in the 2000s (Mubarok, 2009).

Murianto (2014), Kanom (2015), Sriwi (2016), Yudarta (2016), and Trisnawati (2016) have all constructed Lombok as an island that has considerable potential to attract tourists and develop a tourism sector. Murianto (2014), in his study of tourist attractions and public perceptions in Central Lombok, focused on ecotourism, highlighting such waterfalls as Stokel, Benang Kelambu, and Kelewon. He noted that public perceptions of tourism have been both positive and negative. Kanom (2015), meanwhile, developed a conservation strategy that underscored the importance of increasing public awareness of the need to maintain a clean and comfortable environment, recognize cultural attractions, better the 
quality of socio-cultural life, increase promotions through print and electronic media, improve human resources, and ensure public participation in maintaining security. Sriwi (2016) offered a strategy for optimizing the use of Kuta Beach, Central Lombok, namely increasing the number of tourist attractions, improving security and comfort, and improving human resources (Sriwi et al, 2016). Meanwhile, distinguishing himself from the environmental approaches of Murianto, Kanom, and Sriwi, Yudarta (2016) emphasized the artistic potential of Lombok, offering a multicultural performance art package that combined Sasak and Balinese art. Finally, Trisnawati (2016) offered a cross-cultural collaboration in performance art to increase Mataram's tourism potential.

Efforts to increase tourism in Lombok have also dealt with security concerns. For example, Khalik (2014) focused on increasing tourists' comfort and safety to Kuta Beach, Lombok. According to Khalik (2014), the local community's participation in promoting the safety and tourism of tourists remains limited. It has negatively affected the number of tourists visiting the beach.

Zainuri and Zanuar have conducted a further examination of tourism in Lombok. Zainuri et al. (2016) highlighted the potential of diverse local cuisines in increasing tourism in Lombok. According to Zainuri et al. (2016), local food sales reached Rp 248 billion in 2014. Meanwhile, Zanuar (2017) examined trends among couples visiting Gili Trawangan, finding that they were predominantly Europeans between 25 and 44 .

Research into tourism in Lombok has been complemented by efforts to increase regional income from the tourism sector in what may be termed Lombok's economization. This economization of Lombok has been revealed by Satrya (2018a) by analyzing the discourses in the novel Ketika Cinta Tak Mau Pergi (When Love Will not Go). Lombok's economization has included the development of ecotourism, culinary tourism, and cultural tourism, which has necessitated the expansion of natural tourist attractions, management of foodstuffs, and administration of arts programs. It has all been done in the name of increasing regional income. Meanwhile, the economic discourse in the novel Ketika Cinta Tak Mau Pergi may be categorized as the economization of Lombok through factory construction and expansion (Satrya HD, 2018a). In developing the tourism sector, Lombok has experienced capitalization (Karim, 2008), with many foreign concerns investing their capital in tourism attractions such as Senggigi (Karim, 2008). According to Karim (2008, p. 95), "since 1989, Senggigi has become an arena for the contestations of major investors and ... this has characterised the development of tourism in Senggigi."

\section{CONCLUSION}

Europe, Netherland, has constructed the discourse of Lombok as a tourism attraction. In the novel Medulla Sinculasis, the character Johanna went on a honeymoon to Lombok and purchased a painting called Medulla Sinculasis. This painting, which Nuruda saw on auction at the VincentVan Gogh Museum, led him to travel to Lombok. There, he transformed from a touristinto a social activist. He was no longer a mere visitor. His travels from Europe to Lombok were part of a discursive movement, as the painting Medulla Sinculasis-more specifically, its construction of Lombok-drew Nuruda's interest. He traveled to Lombok as a tourist and met Husin Nanang, the artist who painted Medulla Sinculasis. This meeting inspired him to become an activist, fighting to protect Ampenan's marginal people's rights through art. However, Nuruda's movement failed. Unknowingly, Nuruda entered the world of Tegar, the subject of and inspiration for the painting. Nuruda judged Medulla Sinculasis based not on his own experiences with Tegar, but rather his experiences as an art lover. It distinguished him from Johanna, a nurse who had once treated a patient who suffered from medulla sinculasis and referred to this experience in giving the painting its title. It is the discourse behind the painting that ultimately brought Nuruda to Lombok.

The novel Medulla Sinculasis is presented as a tourist guide to Lombok. The narrative begins with Nuruda's business trip to Europe, during which he visited the Van Gogh Museum and saw the painting Medulla Sinculasis. Nuruda became interested in travelling to Lombok after seeing the painting and did so with little but his tourist map. As such, the narrative of Nuruda's experiences in Lombok provides a guideline of sorts for 
tourists visiting Mataram. Such a tourism narrative is presented primarily through dialogue between Nuruda and Vandesa. In the novel, the narrator presents tourism in Lombok from an outside perspective, rather than a local one, and lacks detail in his presentation of the island's tourist attractions.

Lombok's construction as a tourist destination is the discursive construction of
Lombok's economization, as tourism in Lombok has experienced capitalization (Karim, 2008). As such, the novel Medulla Sinculasis is part of the tourism discourse in Lombok. As part of this discourse, the novel Medulla Sinculasis attempts to attract readers to the island. It may thus be seen as being part of the economization of Lombok, the capitalization of Lombok.

\section{REFERENCES}

Asnawi. (2005). Respons Kultural Masyarakat Sasakterhadap Islam. Ulumuna, IX(1), 1-19.

Bear, R. Y., Mitsui, J., McAuley, J., Kuo, A., Cook-lynn, E., \& Silver, P. (1987). Ethnicity in Poetry. Wicazo Sa Review, 3(1), 8-22.

Budiwanti, E. (2000). Islam Sasak: Waktu Telu versus Waktu Lima. Yogyakarta: LKIS.

Department of Education and Culture (Depdikbud). (1988). Sejarah Daerah Nusa Tenggara Barat. Department of Education and Culture.

Fauzan, A. (2013). Mitologi Asal-Usul Orang Sasak (Analisis Struktural pemikiran orang Sasak dalam Tembang Doyan Neda). Universitas Gadjah Mada.

Fernandez, I. P. (2009). Representing Third Spaces, Fluid Identities, and Contested Spaces in Contemporary British Literature. Atlantis, 31(2), 143-160.

Gilman, S. L. (1998). Introduction: Ethnicity-Ethnicities-Literature-Literatures. PMLA, 113(1), 19-27.

Hardiningtyas, P. R. (2015). Manusia dan Budaya Jawa dalam Roman Bumi Manusia: Eksistensialisme Pemikiran Jean Paul Sartre. Aksara, 27(1), 83-98.

Hunter, C. L. (2004). Local Issues and Changes: The Post-New Order Situation in Rural Lombok Sojourn: Journal of Social Issue in Southeast Asia, 19(1), 100-122.

Iben, P. (2011). Medulla Sinculasis, Suatu Hari di Bulan Desember. Mataram: Institut Rumah Arus.

Illustrated Tourist Guide to East Java, Bali, and Lombok. (1914). The Official Tourist Bureau. http://khastara.perpusnas.go.id/web/detail/139203/lombok

Kanom. (2015). Strategi Pengembangan Kuta Lombok Sebagai Destinasi Pariwisata Berkelanjutan. Jumpa, 1(2), 25-42.

Karim, A. (2008). Kapitalisasi Pariwisata dan Marginalisasi Masyarakat Lokal. Yogyakarta: Genta Press.

Khalik, W. (2014). Kajian Kenyamanan dan Keamanan Wisatawan di Kawasan Pariwisata Kuta Lombok. Jumpa, 1(1), 23-42.

Kurnia, M. D. (2015). Warna Lokal Melayu pada Novel Ayah Karya Andre a Hirata. Deiksis, 141-163.

Lukman, L. (2006). Tata Budaya Adat Sasak di Lombok. s.n. 
Lukman, L. (2008). Pulau Lombok dalam Sejarah. (E. Rajagukguk, ed.). s.n.

May, A., Ali, Y., Mahrip, Winangun, Yah, \& Duliun, M. M. (1989). Tata Kelakukan di Lingkungan Pergaulan Keluarga dan Masyarakat Nusa Tenggara Barat. Jakarta: Department of Education and Culture.

Mintosih, S., Lestariningsih, A. D., \& Herliswani. (1999). Pengkajian Nilai Budaya Naskah Babad Lombok. Jakarta: Department of Education and Culture.

Mubarok, M. Z. (2009). NTB Bersaing. Mataram: BAPEDA.

Murianto. (2014). Potensi dan Persepsi Masyarakat serta Wisatawan Terhadap Pengembangan Ekowisata di Desa Aik Berik, Lombok Tengah. Jumpa, 1(1), 43-64.

Oliver, L. J. (1991). Deconstruction or Affirmative Action : The Literary-Political Debate over the " Ethnic Question." American Literary History, 3(4), 792-808.

Putra, I. N. D. (2017). Eksistensi Puisi Indonesia di Bali pada Era Kolonial. Aksara,29(2), 171-182.

Putra, I. Y. D. (2011). The Development of Indonesian Literature From Bali. In A Literary Mirror: Balinese Reflections on Modernity and Identity in the Twentieth Century (IND Putra, ed.). Leiden: Brill. (pp. 27-66).

Putri, N. Q. Hadi. (2016). Kritik SosialSuku Dayak Benuaq dalam Novel "Api Awan Asap" karya Korrie Layun Rampan. Bahastra, 35(2), 65-73.

Ramachandran, I., \& Hashim, R. S. (2014). Revalorising Paraiyar Ethnic Identity through Literary Writings. GEMA Online Journal of Language Studies, 14(3), 243-253. https://doi.org/10.17576/GEMA-2014-1403-15

Satrya HD, D. (2018a). Feudalism versus Capitalism: The Changing Representation of Lombok in Nadira Khalid's Novel Ketika Cinta Tak Mau Pergi. 3L: Language, Linguistics, Literature, 24(4), 115-127. https://doi.org/10.17576/3L-2018-2404-09

Satrya HD, D. (2018b). Strategi Kiki Sulistyo dalam Arena Sastra Indonesia. Haluan Sastra Budaya, 2(1), 41-59.

Sesnic, J. (2007). From Shadow to Presence: Representation of Ethnicity in Contemporary American Literature. New York: Rodopi.

Soedjijiono. (2009). Menuju Teori Sastra Indonesia: Membangun Teori prosa Fiksi berbasis NovelNovel Kearifan Lokal. Atavisme, 12(1), 47-63.

Sriwi, A., Sudiarta, I. N., \& Mahadewi, N. P. E. (2016). Strategi Pengembangan Kuta Lombok Sebagai Destinasi Pariwisata. IPTA, 4(1), 61-65.

Subardini, N. N. (2011). Stratifikasi Masyarakat Bali dalam "Tarian Bumi" dan "Kenanga" karya Oka Rusmini. Atavisme, 14(2). 214-227.

Suroso. (2011). Kepriyayian Tokoh dalam Novel Warna Lokal Jawa dan Sumbangannya dalam Pengembangan Karakter Bangsa. Litera, 10(2), 183-191.

Suwignyo, H. (2013). Makna Kearifan Budaya Jawa dalam Puisi Pariksit, Telinga, Dongeng Sebelum Tidur, dan Asmaradana. Bahasa Dan Seni, 41(2), 181-190. 
Syakur, A. A. (2006). Islam dan Kebudayaan: Akulturasi Nilai-Nilai Islam dalam Budaya Sasak. (Herawati, ed.). Yogyakarta: Adab Press.

Trisnawati, I. A. et al. (2016). "Strands of Gumi Sasak Pearls": Harmony-based Tourism Product in Mataram City, West Nusa Tenggara Barat. Artand Culture, 31(3), 295-307.

Wijanarti, T. (2015). Representasi Perempuan Bergelar Nyai dalam Cerita Rakyat Kalimantan Tengah. Aksara, 27(2), 207-215.

Wildan. (2013). Kearifan Lokal dalam Novel Seulusoh Karya D. Kemalawati. Bahasa Dan Seni, 41(1), $30-39$.

Yudarta, I. G. (2016). Potensi Seni Pertunjukan Bali sebagai Penunjang Pariwisata di Kota Mataram, Nusa Tenggara Barat. Mudra, 31 Nomor 1, 37-53.

Zaelani, K. (2007). Satu Agama Banyak Tuhan: Melacak Akar Sejarh Teologi Waktu Telu. Mataram: Media Presindo.

Zainuri, Zaini, A., Werdiningsih, W., \& Sjah, T. (2016). Keberagaman Pangan Lokal di Pulau Lombok untuk Menunjang Pengembangan Pariwisata. Agritech, 36(2), 206-218.

Zanuar, Z. A., Sendra, I. M., \& Mananda, I. G. S. (2017). Preferensi Wisatawan Berpasangan Mancanegara terhadap Produk Wisata di Gili Trawangan, Lombok Utara, Nusa Tenggara Barat. IPTA, 5(1), 45-52.

Zulkarnain. (2009). Tuan Guru Bajang: Berpolitik dengan Dakwah dan Berdakwah dengan Politik. (I. A. Hakim, ed.) (2nd ed.). East Java: Kaysa Media. 
LiNGUA Vol. 15, No. 2, December 2020 • ISSN 1693-4725 • e-ISSN 2442-3823 